\title{
Imaging Features of Intraosseous Myofibroma of the Jaws: A Case Report and Literature Review
}

\author{
Newaz ZA*, Pannu V, Kennedy J, Barghan S, Kashtwari DN and Nair MK \\ Division of Radiology, Department of Oral and Maxillofacial Diagnostic Sciences, College of Dentistry, University of \\ Florida, Gainesville, FL
}

*Corresponding author: Newaz ZA, Division of Radiology, Department of Oral and Maxillofacial Diagnostic Sciences, College of Dentistry, University of Florida, Gainesville, FL, E-mail: newazz@gmail.com

Citation: Newaz ZA, Pannu V, Kennedy J, Barghan S, Kashtwari DN, et al. (2016) Imaging Features of Intraosseous Myofibroma of the Jaws: A Case Report and Literature Review. J Adv Radiol Med Image 1(1): 102. doi: 10.15744/2456-5504.1.102

\section{Received Date: April 11, 2015 Accepted Date: July 23, 2016 Published Date: July 26, 2016}

\begin{abstract}
Myofibroma is a rare perivascular tumor that can present in soft tissue, or less commonly, intraosseously. A twelve year-old female patient's case of myofibroma in the mandible is reported with clinical presentation, imaging findings, histologic findings, treatment, and short-term follow-up. A literature search was conducted to provide an update, and to tabulate imaging features of central myofibroma of the jaws to better understand the common features and demographic parameters of the relatively small number of cases that have been reported. All reported intraosseous maxillofacial sites are in the mandible with two cases in the maxilla. They can grow rapidly and exhibit other aggressive features. They tend to be seen predominantly in the first two decades of life. Broadly, the lesion appears well-defined, radiolucent/lowly attenuated on radiographs/CT respectively, with the possibility of expansion, cortical perforation, and internal calcification. Effects on teeth and neurovascular structures are variable. Better understanding of this rare condition may assist the radiologist in consideration to include myofibroma in the differential diagnosis if the imaging findings meet certain parameters.
\end{abstract}

Keywords: Intraosseous Myofibroma; Computed tomography; Magnetic resonance; Case Report; Oral Pathology

\section{Introduction}

The terminology regarding myofibroma has historically had some variation and confusion. Older terms reported in the literature include congenital fibrosarcoma, congenital generalized fibromatosis, congenital mesenchymal hamartomas, and infantile myofibroma/myofibromatosis. Differentiation between solitary and multicentric variants of the disease led to the distinction of myofibroma from myofibromatosis respectively [1]. The World Health Organization (WHO) classification of tumors report from 2002 [2] acknowledged this difference and categorized them under "fibroblastic/myofibroblastic tumors". In the latest WHO classification from 2013, myofibroma was moved from this group to the perivascular tumor group, due to "morphologic continuum" between it and myopericytoma [3].

Myofibromas are benign mesenchymal perivascular tumors comprised of myoid tissue. They are predominantly seen in children, and can also develop in adults [4,5]. Among the more common locations are the head, neck and trunk. They are predominantly soft tissue tumors that arise within dermis, subcutis, or soft tissue, but intraosseous presentation is sometimes seen. The mandible is a common intraosseous site. Myofibromas can be solitary or multifocal, the latter mostly in the infant age group. Solitary variants are overwhelmingly more common. Visceral involvement is uncommon, but can present in generalized myofibromatosis, and prognosis has been reported to be unfavorable in such cases [5].

Histologic features include fascicles of plump, myoid spindle cells, with elongated nuclei and eosinophilic cytoplasm, and possible myxomatous fibrous connective tissue. There is usually presence of capillaries or perivascular cells. Immunohistochemical analysis is typically positive for smooth muscle actin (SMA) and/or muscle-specific actin (MSA) [5].

Most tumors have been described as radiolucent/low-attenuation, well-defined, and expansile, with possibility of internal calcification. A recent extensive review of fibroblastic and myofibroblastic tumors of the head and neck summarizes computed tomography (CT) and magnetic resonance (MR) imaging findings as follows: CT findings include variable density, occasional calcification, necrosis and bone erosion; MR characteristics include hypointense signal in T1-weighted images and hypo- or hyperintense signal in T2-weighted images. The same review also describes contrast administration to yield a strong and peripheral signal, and includes the possibility of sclerotic margins in plain film around the radiolucent lesions [6].

It appears to be widely reported that complete surgical resection is typically successful (for solitary lesions) without significant adverse sequelae and that recurrence rates are low $[7,8]$. In the case of multiple lesions in infancy, spontaneous regression has been reported. Tumor regression may depend upon chemotherapy in multicentric life-threatening forms [6]. 


\section{Methods}

Referral data, treatment notes from patient visits, radiographs, faculty approved radiology reports, biopsy reports, and clinical photos were obtained via the patient's dental and medical records from the University of Florida College of Dentistry and Shands Hospital, and reported in our case series. Imaging findings of our case were tabulated among all other readily searchable intraosseous myofibromas of the jaws in the literature for entry of demographic information and imaging features. The term "myofibroma" was searched with the terms "solitary", "central", "intraosseous", "mandible", "maxilla", and "jaws" in MEDLINE to include papers for the tabulation. A few studies that used a previous terminology of myofibroma were reported in some of the included papers that led to further consideration. Inclusion criteria for the tabulation were a) presence of some form of diagnostic images in the article, b) presence of some form of description of the findings, c) presence of an intraosseous myofibroma in the mandible or maxilla, and d) description or mention of histological evidence to support myofibroma as the diagnosis. Papers not in English as the primary language were excluded. The inclusion strategies yielded 23 papers that contained reports of cases to include in our tabulation of imaging findings [1,4,7,9-28]. The total number of patients with usable, individualized imaging data included in the selected papers was 30 , and by including our reported case, the total was $n=31$. Simple descriptive statistics were utilized to analyze categorical data.

\section{Case Report}

A 12 year-old African American female presented to the University of Florida Oral and Maxillofacial Pathology clinic via referral from a practicing dentist in a nearby locality. The patient was seen in the clinic five days after the referral was received by the school. At the time of examination in the Oral Pathology clinic, the swelling was reported to have been present for approximately one month's duration. The dentist included a panoramic image in the referral, which revealed a well-defined, radiolucent lesion in the right posterior mandible in the region of the angle. There was no frank evidence of internal calcification or contents. The inferior cortical margin appeared disrupted (Figure 1). The patient reported that she could notice a swelling in her right jaw for the past month (Figure 2). An inter-clinic referral to the Oral Surgery clinic was made and the patient was seen about two weeks later. At this office visit, patient interview was negative for pain, change in occlusion, numbness, tingling, drainage, dysphagia, dysphonia, and trismus. Clinical examination revealed a hard swelling with no fluctuance, tenderness to palpation, erythema, or symptoms in the temporomandibular joints. There were no reported abnormalities with vitality testing in the quadrant. There was partial eruption of tooth \#31 with some buccal swelling detected intraorally.

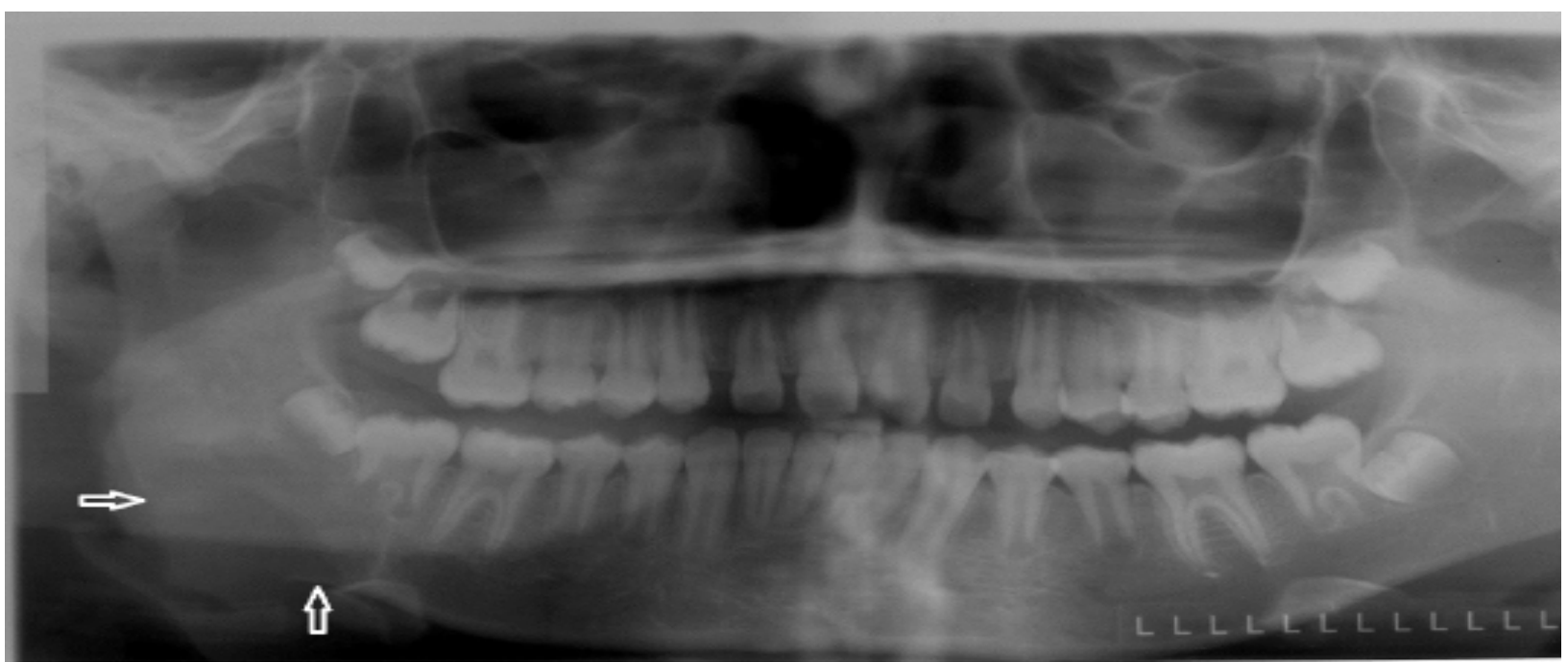

Figure 1: Preoperative panoramic radiograph depicting a well-defined radiolucent entity in the right angle of the mandible
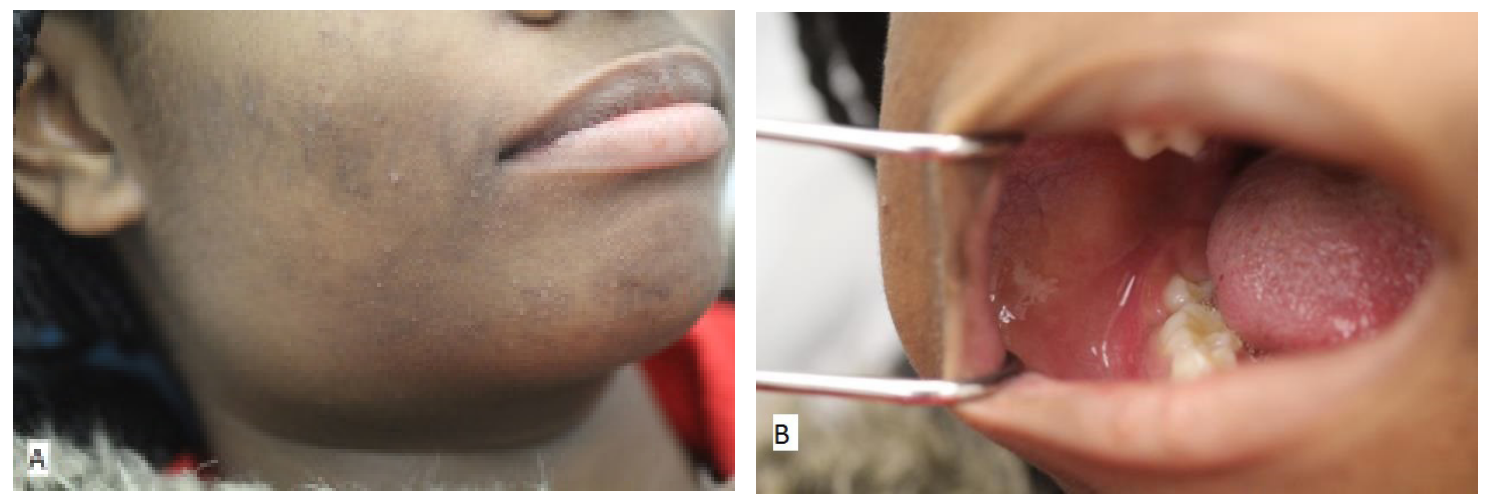

Figure 2: Clinical photos showing a) a visible swelling in the region of the right mandibular angle and b) associated intraoral swelling 
A cone beam CT (CBCT) was obtained and interpreted by Oral and Maxillofacial radiology faculty. Select slices and views are depicted in Figure 3, including multiplanar views and a volume rendered image. The exam revealed a well-defined, mostly corticated low-attenuation area with evidence of faint calcification within. It was located in the right posterior mandible extending from the distal root of \#31 to the right angle of the mandible anteroposteriorly and from the midroot level of \#31 to the inferior margin of the mandible superoinferiorly. Buccolingually it extended from buccal to lingual cortex. There was thinning and significant expansion of the buccal, lingual and inferior cortical margins. Perforation of some cortical boundaries was possible but was difficult to discern due to volume averaging artifacts in CBCT. The inferior alveolar canal was displaced superiorly with possible effacement of its borders. The follicle of \#32 was in close proximity to the lesion. In the impression, benign mixed density entities such as calcifying cystic odontogenic tumor, calcifying epithelial odontogenic tumor, ameloblastic fibro-odontoma, and juvenile ossifying fibroma were included in the differential diagnosis with mention of the possibility of vascular lesions such as hemangioma. Multi-detector CT (MDCT) imaging and histopathologic evaluation were recommended.
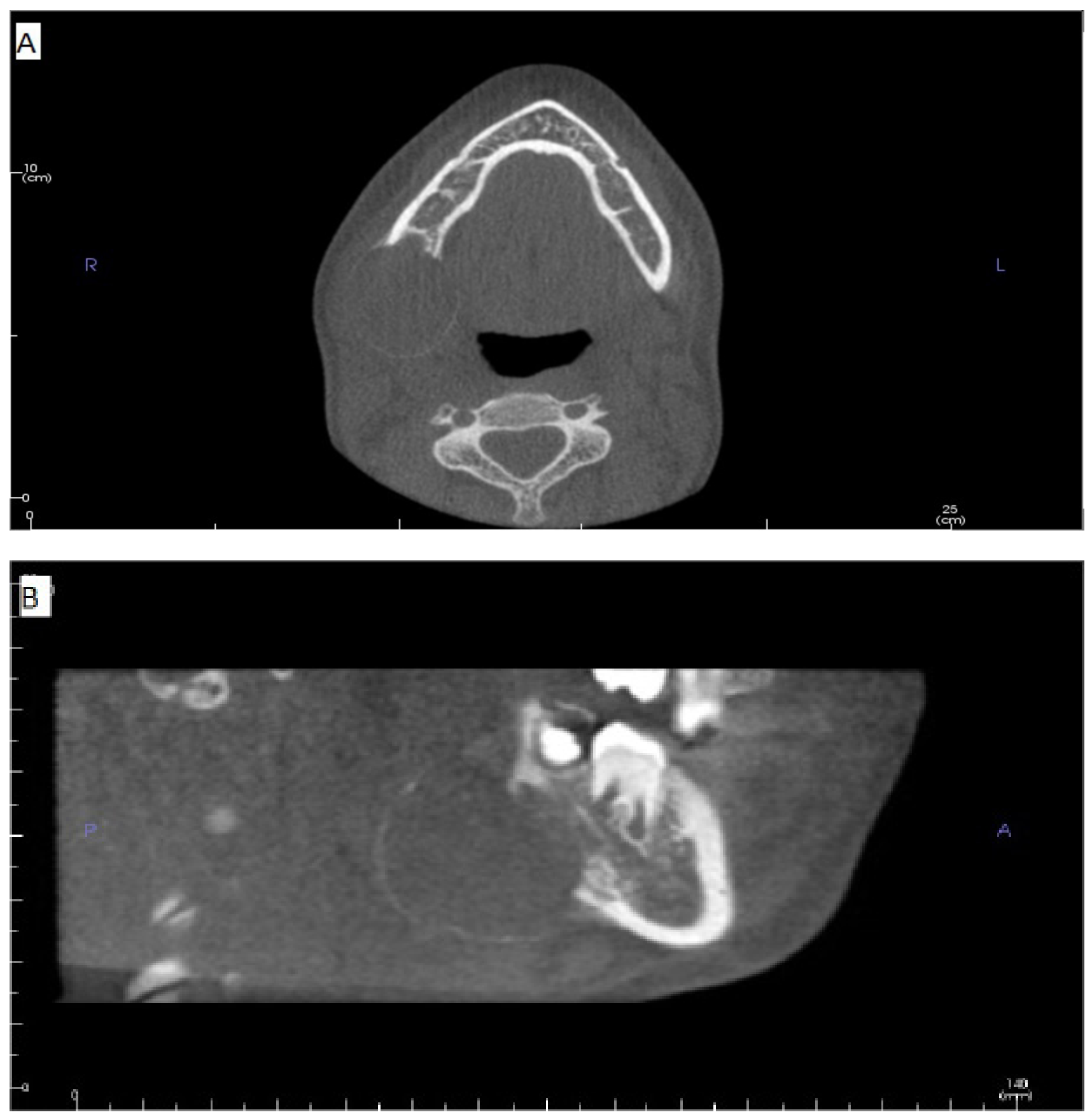

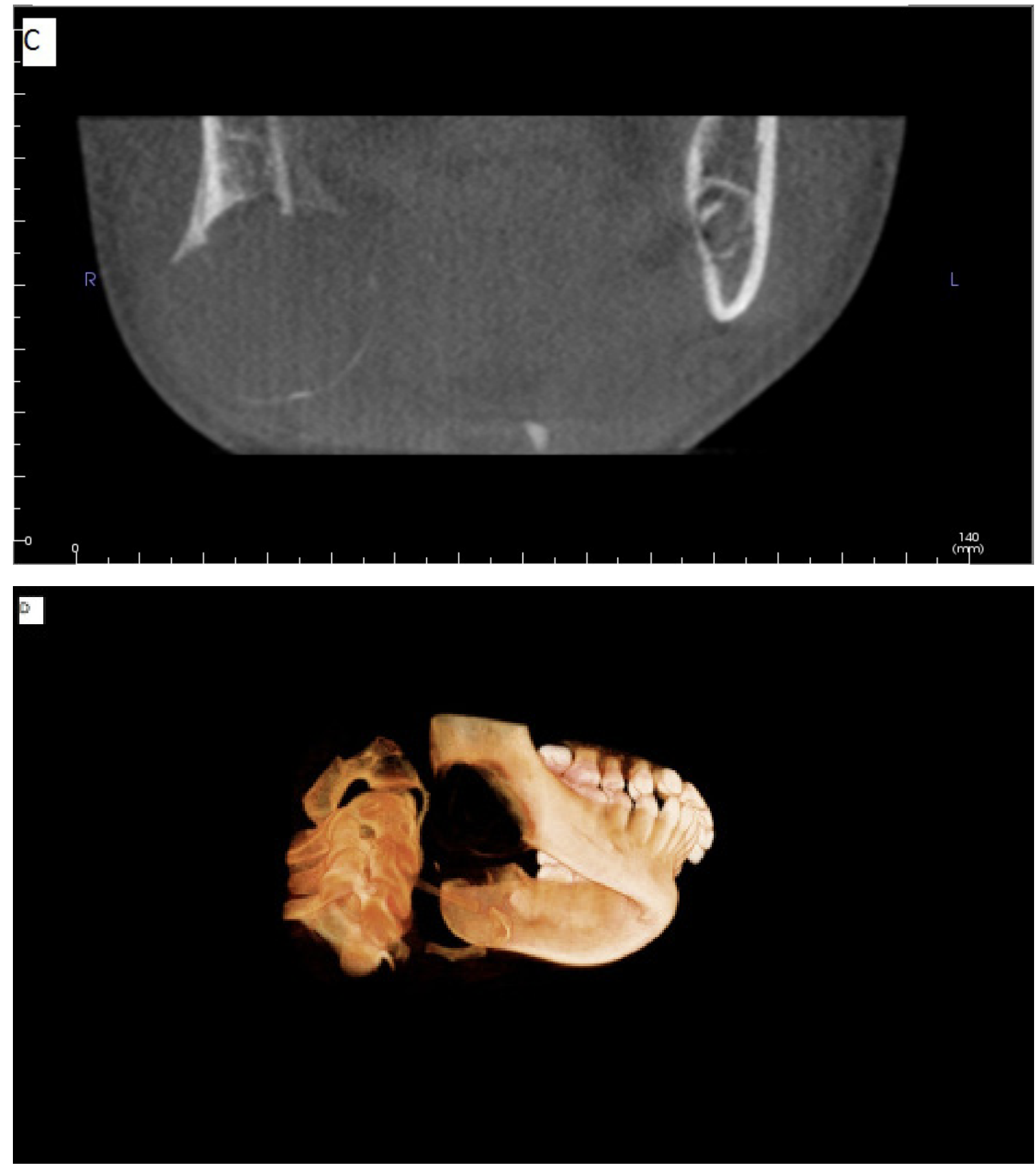

Figure 3: Cone beam CT views of the lesion, left to right and top to bottom: a) axial, b) sagittal, c) coronal, and d) 3D-volume rendered images, showing a low-attenuation, well-defined lesion with a thin cortical rim

Approximately three months after the initial visit with the clinical exam and cone beam CT, a biopsy was performed as per recommendation. The patient was under IV conscious sedation and local anesthesia. A sulcular incision, mucoperiosteal flap, and bone removal allowed access to the contents of the lesion. The inferior alveolar neurovascular bundle was visualized and retracted lingually with no injury. An incisional biopsy ensued with acquisition of the desired tissue sample. The follicle of \#32 was superior to the lesion and was extracted at the time of biopsy. The flap was sutured after copious irrigation.

The tissue was sent to the University of Florida Oral and Maxillofacial Pathology service for histochemical processing and interpretation. Gross examination of the tissue specimen revealed gray/tan/brown irregular pieces of soft tissue as well as hard tissue. Microscopic examination revealed cellular and acellular myxomatous fibrous connective tissue interspersed by osteoidlike material, hyalinized eosinophilic product and calcified structures. There were collagen bundles with plump spindle-shaped fibroblastic cells. The connective tissue was of varying levels of cellularity. Fibroblasts, capillaries, islands of odontogenic epithelium, and some irregular calcified material were noted. Immunohistochemical analysis revealed staining for smooth muscle, skeletal muscle, and neural tissue. The majority of lesional cells were strongly reactive for the smooth muscle marker SMA, indicating a myofibroblastic proliferation. The diagnosis was myofibroma. 
Two weeks after the biopsy appointment, there were no significant adverse complications. The treatment plan proposed was extraction of teeth \#30 and 31, then resection. Approximately two months later, the teeth were extracted, and an operating room appointment was scheduled for two months from the date of tooth extractions.

Before the surgery and following extraction of teeth, a multi-detector Computed Tomography (MDCT) study was ordered (Figure 4). The date of this exam was approximately 6 months after the cone beam CT study. No intravenous contrast was administered. The exam demonstrated a mainly solid-appearing, low-density mass centered in the angle of the right mandible with expansile features and internal mineralized component. There was surrounding periosteal reaction along the buccal aspect of the lesion. The inferior alveolar canal appeared to be displaced superiorly as noticed in the CBCT study. Although there was thinning of the bony margin along the posterior aspect of the lesion, there was no definite extraosseous component. There was a single asymmetrically prominent right level 1 lymph node just inferomedial to the lesion with no definite pathologic lymphadenopathy by size criteria or abnormal morphology.
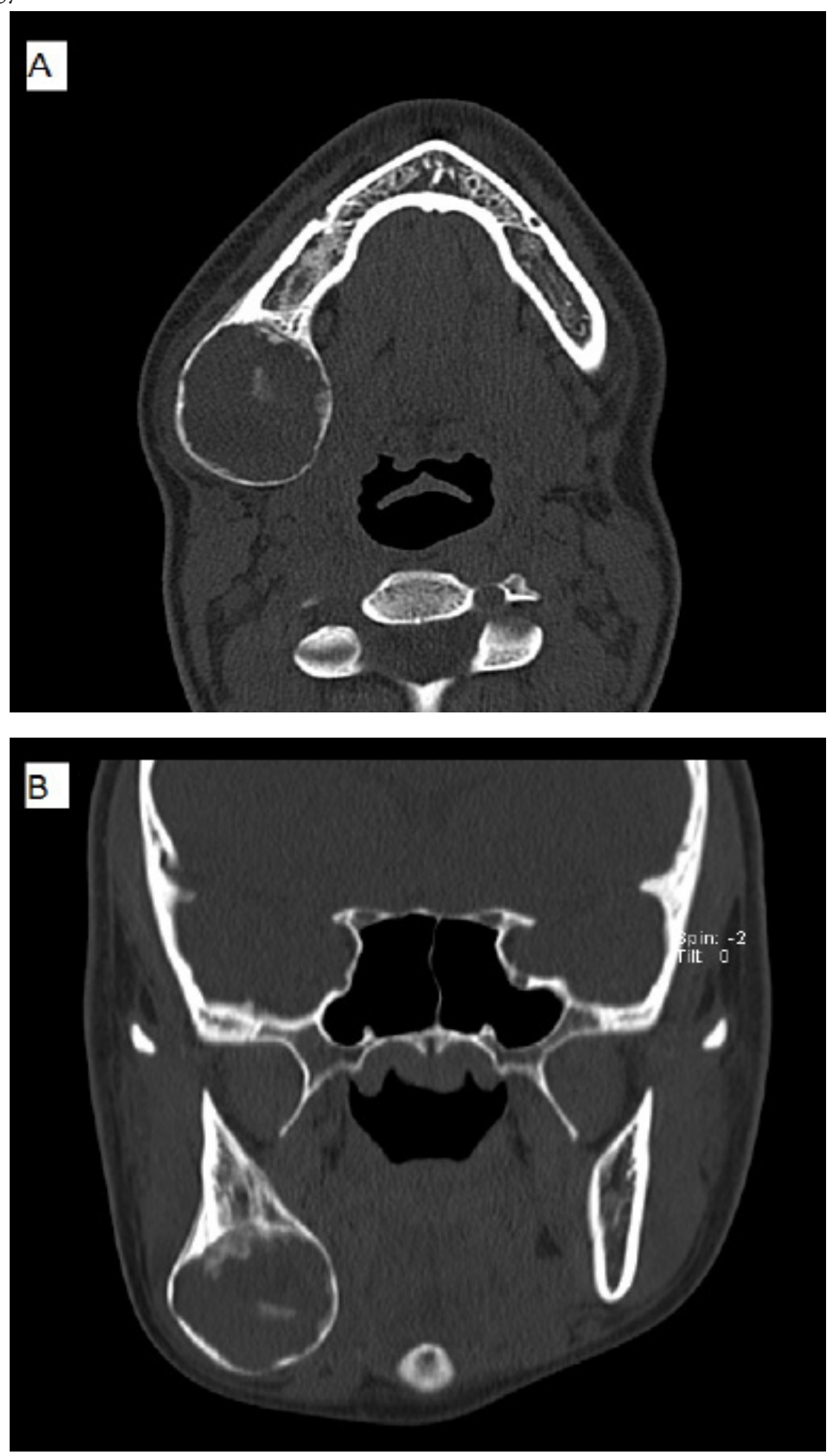

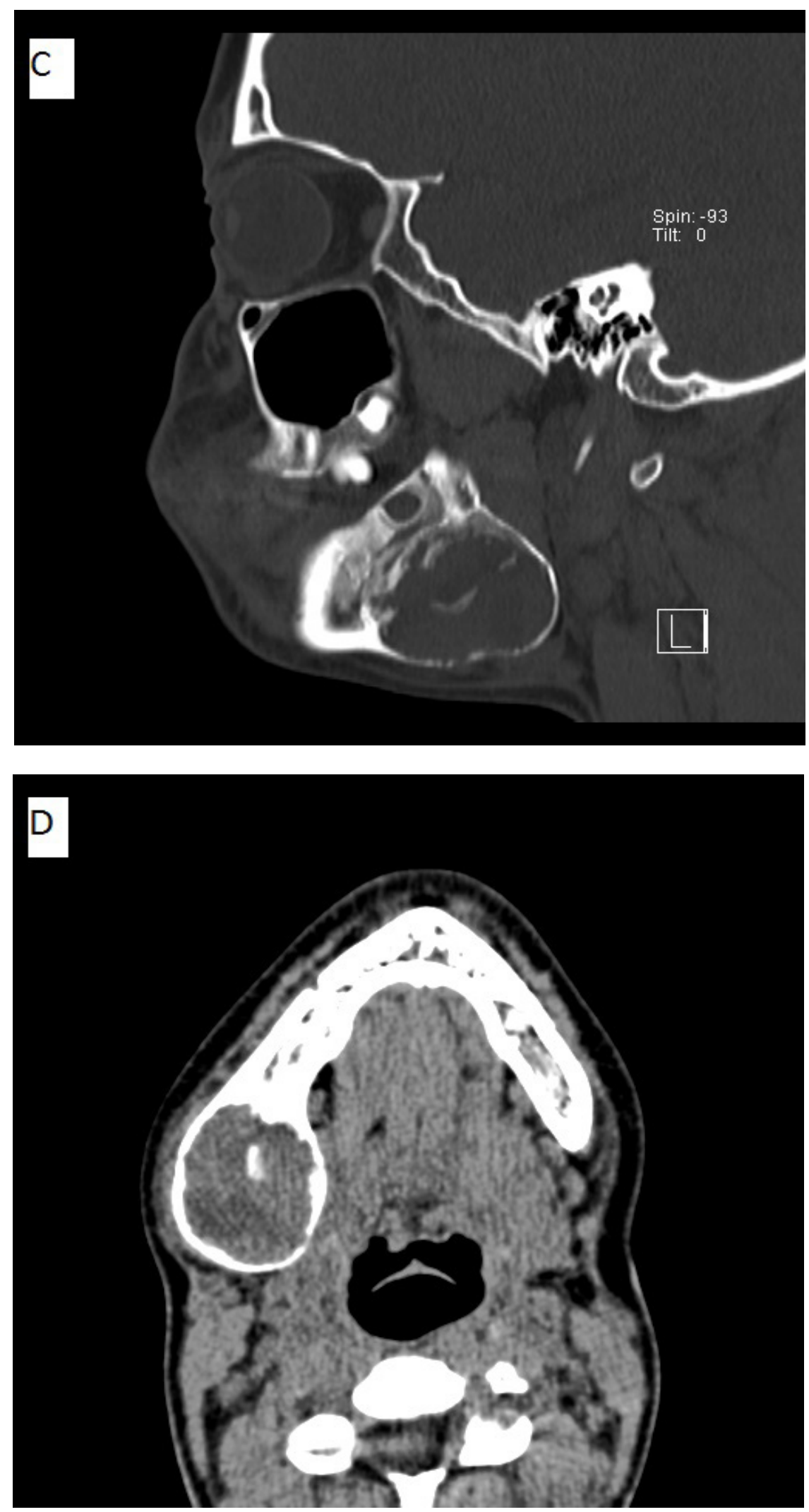

Figure 4: Non-contrast multi-detector CT images. Bone-window views are shown for a) axial, b) coronal, and c) sagittal sections. A soft-tissue axial view is shown in d) All images depict a well-defined low-attenuation area with a cortical rim and evidence of calcification within

Segmental resection and reconstruction with iliac graft and surgical fixation hardware were carried out in the operating room at the appointed date with no known complications. A post-operative panoramic image reveals good approximation of the graft segment to the native mandibular segments, fixated with surgical hardware. There were no known complications from the surgery, except right $\mathrm{V} 3$ paresthesia, which was expected given the area of the segmental resection. 


\section{Literature Review}

The literature search was conducted in accordance to the method described earlier. Table 1 shows each reported case of intraosseous myofibroma in the jaws. Wherever applicable, data from such studies, including age, gender, location of the lesion, and various imaging feature categories were recorded. Imaging features include modality, definition of borders, internal appearance, effects on nearby structures, and other features such as periosteal reaction. If trauma was reported in the patient's history prior to presentation with the lesion, it was recorded. The types of imaging modalities were included in the table but were not part of any statistical analysis.

\begin{tabular}{|c|c|c|c|c|c|c|c|c|c|c|c|c|c|c|}
\hline Study $(n=31)$ & Year & $\begin{array}{l}\mathrm{S} \\
\mathrm{e} \\
\mathrm{x}\end{array}$ & $\begin{array}{l}\mathrm{A} \\
\mathrm{g} \\
\mathrm{e}\end{array}$ & Imaging & Location & $\begin{array}{l}\text { Bor- } \\
\text { ders }\end{array}$ & $\begin{array}{l}\text { Inter- } \\
\text { nal } \\
\text { struc- } \\
\text { ture }\end{array}$ & $\begin{array}{l}\text { Loc- } \\
\text { ular- } \\
\text { ity }\end{array}$ & $\begin{array}{c}\text { Ef- } \\
\text { fects } \\
\text { on } \\
\text { teeth }\end{array}$ & $\begin{array}{c}\text { Effects on } \\
\text { neuro- } \\
\text { vascular } \\
\text { structures }\end{array}$ & $\begin{array}{l}\text { Expan- } \\
\text { sion }\end{array}$ & $\begin{array}{l}\text { Cortical } \\
\text { perfora- } \\
\text { tion }\end{array}$ & $\begin{array}{c}\text { Peri- } \\
\text { osteal } \\
\text { reaction }\end{array}$ & $\begin{array}{c}\text { Trau- } \\
\text { ma }\end{array}$ \\
\hline This case & 2015 & $\mathrm{~F}$ & 12 & $\begin{array}{l}\text { CT, } \\
\text { CBCT, } \\
\text { pan }\end{array}$ & $\begin{array}{l}\text { Posterior } \\
\text { mandible }\end{array}$ & $\begin{array}{l}\text { WD, } \\
\text { PC }\end{array}$ & $\begin{array}{l}\text { RL, LA, } \\
\quad \mathrm{Ca}\end{array}$ & $\mathrm{U}$ & $\mathrm{D}$ & $\mathrm{D}$ & Y & $\mathrm{Y}$ & $\mathrm{Y}$ & NR \\
\hline Lopes RN et al [4] & 2015 & $\mathrm{~F}$ & 2 & CT & $\begin{array}{l}\text { Posterior } \\
\text { mandible }\end{array}$ & WD & LA & $\mathrm{U}$ & NR & NR & $\mathrm{Y}$ & $\mathrm{Y}$ & NR & $\mathrm{Y}$ \\
\hline Lee $\mathrm{Y}$ et al [9] & 2014 & $\mathrm{~F}$ & 31 & $\begin{array}{c}\mathrm{CT} \\
\operatorname{pan}(\mathrm{n} / \mathrm{a})\end{array}$ & $\begin{array}{l}\text { Posterior } \\
\text { mandible }\end{array}$ & $\begin{array}{l}\text { WD, } \\
\text { C }\end{array}$ & LA & $\mathrm{U}$ & NR & NR & Y & NR & NR & NR \\
\hline Rai B et al [10] & 2014 & $\mathrm{~F}$ & 5 & $\begin{array}{c}\text { Pan, CT } \\
\text { w/c }\end{array}$ & $\begin{array}{l}\text { Posterior } \\
\text { mandible }\end{array}$ & WD & $\mathrm{RL}, \mathrm{LA}$ & $\mathrm{U}$ & LLD & NR & Y & Y & Y & NR \\
\hline Urs $A B$ et al [11] & 2014 & M & 5 & Pan & $\begin{array}{l}\text { Posterior } \\
\text { mandible }\end{array}$ & ID & RL & $\mathrm{U}$ & $\mathrm{D}, \mathrm{R}$ & NR & $\mathrm{Y}$ & $\mathrm{Y}$ & NR & $\mathrm{Y}$ \\
\hline $\begin{array}{c}\text { Damera NCR et } \\
\text { al [12] }\end{array}$ & 2013 & $\mathrm{~F}$ & 13 & $\begin{array}{c}\text { Pan, } \\
\text { CT(n/a) }\end{array}$ & $\begin{array}{l}\text { A-P } \\
\text { maxilla }\end{array}$ & ID & $\begin{array}{l}\text { RL, LA, } \\
\text { Ca }\end{array}$ & $\mathrm{U}$ & $\mathrm{D}, \mathrm{R}$ & NR & Y & $\mathrm{Y}$ & NR & NR \\
\hline Tabrizi R et al [13] & 2013 & M & 1 & $\mathrm{CT}$ & $\begin{array}{l}\text { Posterior } \\
\text { maxilla }\end{array}$ & WD & LA & $\mathrm{U}$ & NR & NR & Y & $\mathrm{Y}$ & NR & $\mathrm{Y}$ \\
\hline $\begin{array}{c}\text { Sundaravel S et al } \\
{[14]}\end{array}$ & 2013 & M & 16 & $\mathrm{CT}$ & $\begin{array}{l}\text { Posterior } \\
\text { mandible }\end{array}$ & $\begin{array}{l}\text { WD, } \\
\text { PC }\end{array}$ & LA & $\mathrm{U}$ & NR & NR & $\mathrm{Y}$ & $\mathrm{Y}$ & NR & NR \\
\hline $\begin{array}{c}\text { Brierley DJ et al } \\
{[15]}\end{array}$ & 2013 & $\mathrm{~F}$ & 43 & Pan & $\begin{array}{l}\text { Anterior } \\
\text { mandible }\end{array}$ & WD & RL & $\mathrm{U}$ & NR & NR & NR & $\mathrm{Y}$ & NR & NR \\
\hline $\begin{array}{c}\text { Haspel AC et al } \\
{[16]}\end{array}$ & 2012 & $\mathrm{~F}$ & 0 & $\mathrm{CT}$ & $\begin{array}{l}\text { Posterior } \\
\text { mandible }\end{array}$ & WD & LA & $\mathrm{U}$ & $\mathrm{D}$ & NR & $\mathrm{Y}$ & $\mathrm{Y}$ & NR & NR \\
\hline Rokos J et al [17] & 2011 & $\mathrm{~F}$ & 5 & Pan & $\begin{array}{l}\text { Posterior } \\
\text { mandible }\end{array}$ & $\begin{array}{l}\text { WD, } \\
\text { C }\end{array}$ & RL & M & $\mathrm{D}$ & NR & $\mathrm{Y}$ & $\mathrm{Y}$ & NR & NR \\
\hline $\begin{array}{c}\text { Nirvikalpa N et } \\
\text { al [18] }\end{array}$ & 2011 & M & 0 & CT & $\begin{array}{l}\text { Posterior } \\
\text { mandible }\end{array}$ & $\begin{array}{l}\text { WD, } \\
\text { PC }\end{array}$ & LA & $\mathrm{U}$ & NR & NR & Y & Y & NR & NR \\
\hline $\begin{array}{l}\text { Ramadorai A et } \\
\text { al [19] }\end{array}$ & 2010 & $\mathrm{~F}$ & 32 & Pan, CT & $\begin{array}{l}\text { Posterior } \\
\text { mandible }\end{array}$ & $\begin{array}{l}\text { WD, } \\
\text { PC }\end{array}$ & RL, LA & M & $\mathrm{D}, \mathrm{R}$ & NR & Y & $\mathrm{Y}$ & NR & NR \\
\hline Souza DP et al [20] & 2009 & $\mathrm{~F}$ & 7 & $\begin{array}{l}\text { Pan, } \\
\text { CBCT }\end{array}$ & $\begin{array}{l}\text { Posterior } \\
\text { mandible }\end{array}$ & $\begin{array}{l}\mathrm{WD} \text {, } \\
\mathrm{C}\end{array}$ & RL, LA & $\mathrm{U}$ & NR & NR & Y & $\mathrm{Y}$ & NR & NR \\
\hline Shibuya Y et al [1] & 2008 & M & 12 & $\begin{array}{c}\text { Pan, CT, } \\
\text { MR, } \\
\text { PET }\end{array}$ & $\begin{array}{l}\text { Posterior } \\
\text { mandible }\end{array}$ & $\begin{array}{l}\text { WD, } \\
\text { PC }\end{array}$ & $\begin{array}{l}\text { RL, LA, } \\
\text { T2S, } \\
\text { IU }\end{array}$ & U & NR & NR & $\begin{array}{c}\text { Mini- } \\
\text { mal }\end{array}$ & $\mathrm{Y}$ & NR & $\mathrm{Y}$ \\
\hline \multirow[t]{4}{*}{ Allon et al [7] } & 2007 & $\mathrm{~F}$ & 0 & $\mathrm{CT}$ & $\begin{array}{l}\text { Anterior } \\
\text { mandible }\end{array}$ & $\begin{array}{l}\text { WD, } \\
\text { PC }\end{array}$ & LA & M & $\mathrm{D}$ & NR & $\mathrm{Y}$ & $\mathrm{Y}$ & NR & NR \\
\hline & & $\mathrm{F}$ & 7 & $\begin{array}{l}\text { PA, pan, } \\
\text { CT }\end{array}$ & $\begin{array}{l}\text { Posterior } \\
\text { mandible }\end{array}$ & ID & $\begin{array}{l}\text { RL, LA, } \\
\text { Ca }\end{array}$ & M & NR & NR & $\mathrm{Y}$ & $\mathrm{Y}$ & $\mathrm{Y}$ & NR \\
\hline & & M & 4 & Pan, CT & $\begin{array}{l}\text { Posterior } \\
\text { mandible }\end{array}$ & WD & RL, LA & M & NR & NR & Y & $\mathrm{Y}$ & NR & NR \\
\hline & & M & 4 & Lat obl & $\begin{array}{l}\text { Posterior } \\
\text { mandible }\end{array}$ & WD & $\mathrm{RL}$ & $\mathrm{U}$ & D & NR & Y & NR & NR & NR \\
\hline Odell et al [21] & 2004 & M & 10 & $\begin{array}{l}\text { Cropped } \\
\text { pan }\end{array}$ & $\begin{array}{l}\text { Posterior } \\
\text { mandible }\end{array}$ & ID & RL & M & $\begin{array}{l}\text { LLD, } \\
\text { D }\end{array}$ & NR & Y & $\mathrm{Y}$ & Y & NR \\
\hline $\begin{array}{c}\text { Seghizadeh et al } \\
{[22]}\end{array}$ & 2004 & M & 20 & Pan, CT & $\begin{array}{l}\text { Posterior } \\
\text { mandible }\end{array}$ & $\begin{array}{l}\text { WD, } \\
\mathrm{PC}\end{array}$ & RL, LA & M & $\mathrm{R}$ & NV & $\mathrm{Y}$ & $\mathrm{Y}$ & NR & NR \\
\hline Oliver et al [23] & 2003 & $\mathrm{~F}$ & 34 & $\begin{array}{c}\text { Pan, PA } \\
\text { ceph, } \\
\text { CT(n/a) }\end{array}$ & $\begin{array}{l}\text { Posterior } \\
\text { mandible }\end{array}$ & $\begin{array}{l}\text { WD, } \\
\text { PC }\end{array}$ & RL & $\mathrm{U}$ & NR & NR & $\mathrm{Y}$ & $\mathrm{Y}$ & NR & NR \\
\hline
\end{tabular}




\begin{tabular}{|c|c|c|c|c|c|c|c|c|c|c|c|c|c|c|}
\hline Study $(n=31)$ & Year & $\begin{array}{l}\mathbf{S} \\
\mathrm{e} \\
\mathbf{x}\end{array}$ & $\begin{array}{l}\text { A } \\
\text { g } \\
\text { e }\end{array}$ & Imaging & Location & $\begin{array}{l}\text { Bor- } \\
\text { ders }\end{array}$ & $\begin{array}{l}\text { Inter- } \\
\text { nal } \\
\text { struc- } \\
\text { ture }\end{array}$ & $\begin{array}{l}\text { Loc- } \\
\text { ular- } \\
\text { ity }\end{array}$ & $\begin{array}{c}\text { Ef- } \\
\text { fects } \\
\text { on } \\
\text { teeth }\end{array}$ & $\begin{array}{c}\text { Effects on } \\
\text { neuro- } \\
\text { vascular } \\
\text { structures }\end{array}$ & $\begin{array}{l}\text { Expan- } \\
\text { sion }\end{array}$ & $\begin{array}{c}\text { Cortical } \\
\text { perfora- } \\
\text { tion }\end{array}$ & $\begin{array}{c}\text { Peri- } \\
\text { osteal } \\
\text { reaction }\end{array}$ & $\begin{array}{c}\text { Trau- } \\
\text { ma }\end{array}$ \\
\hline Oliver et al [23] & 2003 & $\mathrm{~F}$ & 34 & $\begin{array}{c}\text { Pan, PA } \\
\text { ceph, } \\
\text { CT(n/a) }\end{array}$ & $\begin{array}{l}\text { Posterior } \\
\text { mandible }\end{array}$ & $\begin{array}{l}\text { WD, } \\
\text { PC }\end{array}$ & $\mathrm{RL}$ & $\mathrm{U}$ & NR & NR & $\mathrm{Y}$ & $\mathrm{Y}$ & NR & NR \\
\hline Sugatani et al [24] & 1995 & M & 0 & $\begin{array}{c}\text { CT, MR, } \\
\text { NM } \\
\text { Tc-99 }\end{array}$ & $\begin{array}{l}\text { Anterior } \\
\text { mandible }\end{array}$ & WD & $\begin{array}{l}\text { RL, } \\
\text { T2S, } \\
\text { IU }\end{array}$ & $\mathrm{U}$ & $\mathrm{D}$ & NR & $\mathrm{Y}$ & $\mathrm{Y}$ & NR & NR \\
\hline \multirow[t]{3}{*}{ Jones et al [25] } & 1994 & M & 0 & NR & $\begin{array}{l}\text { Posterior } \\
\text { mandible }\end{array}$ & NR & NR & M & NR & NR & NR & NR & NR & NR \\
\hline & & M & 8 & $\begin{array}{l}\text { Cropped } \\
\text { pan }\end{array}$ & $\begin{array}{l}\text { Posterior } \\
\text { mandible }\end{array}$ & ID & RL & $\mathrm{U}$ & $\mathrm{D}$ & NR & $\mathrm{Y}$ & NR & NR & NR \\
\hline & & M & 14 & $\begin{array}{l}\text { Cropped } \\
\text { pan }\end{array}$ & $\begin{array}{l}\text { Posterior } \\
\text { mandible }\end{array}$ & ID & RL & $\mathrm{U}$ & $\mathrm{D}$ & NR & $\mathrm{Y}$ & NR & NR & NR \\
\hline \multirow[t]{3}{*}{$\begin{array}{c}\text { Vigneswaran et } \\
\text { al [26] }\end{array}$} & 1992 & $\mathrm{~F}$ & 2 & Pan & $\begin{array}{l}\text { Posterior } \\
\text { mandible }\end{array}$ & $\begin{array}{l}\text { WD, } \\
\text { PC }\end{array}$ & $\mathrm{RL}$ & $\mathrm{U}$ & $\mathrm{D}$ & NR & $\mathrm{Y}$ & NR & NR & NR \\
\hline & & $\mathrm{F}$ & 11 & $\begin{array}{l}\text { Pan, oc- } \\
\text { clusal }\end{array}$ & $\begin{array}{l}\text { Posterior } \\
\text { mandible }\end{array}$ & WD & $\mathrm{RL}$ & $\mathrm{U}$ & $\mathrm{D}$ & NR & $\mathrm{Y}$ & NR & NR & NR \\
\hline & & M & 6 & $\begin{array}{l}\text { Lat obl, } \\
\text { occlusal }\end{array}$ & $\begin{array}{l}\text { Posterior } \\
\text { mandible }\end{array}$ & $\begin{array}{l}\text { WD, } \\
\text { PC }\end{array}$ & $\mathrm{RL}$ & $\mathrm{U}$ & NR & NR & $\mathrm{Y}$ & NR & NR & NR \\
\hline Mathews el at [27] & 1990 & M & 6 & $\begin{array}{l}\text { Cropped } \\
\text { pan }\end{array}$ & $\begin{array}{l}\text { Posterior } \\
\text { mandible }\end{array}$ & ID & RL & $\mathrm{U}$ & $\mathrm{D}$ & NR & $\mathrm{Y}$ & $\mathrm{Y}$ & NR & NR \\
\hline Slootweg et al [28] & 1984 & M & 0 & Occlusal & $\begin{array}{l}\text { Anterior } \\
\text { mandible }\end{array}$ & WD & $\mathrm{RL}, \mathrm{Ca}$ & $\mathrm{U}$ & $\mathrm{D}$ & NR & $\mathrm{Y}$ & $\mathrm{Y}$ & NR & NR \\
\hline
\end{tabular}

Legend: $\mathrm{NR}=$ not reported, $\mathrm{WD}=$ well-defined, $\mathrm{ID}=$ ill-defined, $\mathrm{PC}=$ partly corticated, $\mathrm{C}=$ corticated, $\mathrm{RL}=$ radiolucent, $\mathrm{LA}=$ low-attenuation, Ca $=$ calcification, T2S = hyperintense T2 MR Signal, IU = increased uptake for PET/nuclear med scan, $\mathrm{U}=$ unilocular, $\mathrm{M}=$ multilocular, $\mathrm{D}=$ displacement, $\mathrm{R}=$ resorption, $\mathrm{LLD}=$ loss of lamina dura, $\mathrm{Y}=$ yes, $\mathrm{NV}=$ not visualized

Table 1: Depiction of demographics, lesion location, imaging modalities reported, imaging features. There were 31 cases $(\mathrm{n}=31)$ found in the literature from 24 articles

\section{Demographics}

There was no obvious gender predilection, with 15 females and 16 males manifesting with the lesion. However, gender distribution for adult lesions remains predominantly female $(\mathrm{M}: \mathrm{F}=1: 4)$, as was recently reported by Lee et al [9]. The mean age in this report was 10 , with $61 \%$ of cases in the first decade of life, $23 \%$ in the second, and the remaining $16 \%$ in adults age 20 and older.

\section{Imaging findings}

The posterior mandible was the dominant location, with $81 \%(25 / 31)$ of cases. The anterior mandible was the site of $13 \%(4 / 31)$, and $6 \%(2 / 31)$ in the maxilla. Borders were variable. Well-defined borders were noted in $74 \%(23 / 31)$ of cases and ill-defined borders in 23\% (7/31). Some form of cortication was observed by our team and/or reported by the authors in $42 \%$ (13/31) of the cases. All reported internal structures were classified in the lucent category, which due to imaging modality was reported as radiolucent (for radiographs), low-attenuation (for CT) or both. Four cases had calcification within (13\%). Twenty three of the lesions were unilocular (74\%) versus 8 multilocular (26\%). Effects on teeth were absent or not reported in $42 \%$ of cases, while $52 \%$ reported tooth displacement, $13 \%$ reported resorption, and 6\% reported loss of lamina dura. Only our case reported specific effects on neurovascular structure, in that the inferior alveolar canal was superiorly displaced. Another report stated that the canal was not visible. Almost all (28/31) cases reported expansion, and an overwhelming majority (23/31) reported perforation or destruction of the cortex. Periosteal reaction was seen in four cases, including ours (13\%). Trauma was reported to precede the presentation of the lesion in four of the cases.

\section{Discussion}

Tabulated results include most but not all reported cases of myofibroma in the jaws, due to our inclusion criteria that were based on availability of diagnostic imaging. As such, descriptive statistics would not comprehensively represent the demographic spectrum of lesion distribution according to age or gender. However, it can be suggested based on our findings that the age distribution for solitary, intraosseous myofibroma of the jaws leans heavily towards the first and second decades of life. Our case further confirms this trend. Reports of the lesion occurring in adults intraosseously in the jaws is exceedingly rare, with the most recent report to date in adults (age 20 being the lower limit) citing that it is the fifth such case [9]. There was some variability with the nature of the borders and internal appearance of the lesions. However, all cases presented in the mandible except two maxillary lesions. Due to variability of presentation, the differential diagnoses reported cover a broad spectrum to include benign tumors with or without calcification as well as malignancy in a few cases. This highlights the paramount importance of histopathological examination 
upon encountering the suspecting entity in diagnostic imaging studies. Expansile or destructive properties have been widely reported. Periosteal response was observed in several papers [7,10,21]. Our case fit the histologic profile of the lesion, with plump spindle-shaped fibroblastic cells, myxomatous fibrous connective tissue, capillaries, positive immunohistochemical results for SMA, among other features.

In the process of the literature review, there were several papers that included imaging changes in the mandible but were not included in the tabulation as their epicenter or tissue of origin was reported to be in the soft tissues near it (such as the gingiva). An example of this would be a myofibroma of the lingual gingiva causing some erosion of the lingual cortex of the mandible that became radiographically evident. In one case, this exhibited an ill-defined appearance around the roots of a tooth [29] that mimicked the appearance of a "floating tooth", a descriptor often used for malignant pathoses. A lesion appearing within the soft tissue of an extraction socket (with no gross bony changes) has been reported as well [30]. So, despite the exclusion of such types of studies, they contain information that would be useful for the clinician or radiologist who encounters imaging findings in the jaws. A retrospective chart review by Abramowicz et al in 2012 examined the behavior of intraosseous versus soft tissue exophytic myofibroma of the jaws, and their findings suggested that the exophytic type is more aggressive than the intraosseous type, despite the two being histopathologically indistinguishable and having no reported recurrences in either of the groups after treatment [31]. Perhaps another review targeting and assessing imaging findings of "paramandibular soft-tissue myofibroma lesions exhibiting osseous changes" or a similar topic would be welcomed in the literature.

A comprehensive, targeted review of intraosseous myofibroma of the mandible by Allon et al published in 2007 [7] included a search strategy similar to ours and tabulated studies reported between 1966 and 2005. We cross-checked all the papers included in that review series, and checked the individual articles for imaging views and descriptions. There were articles that did not have individualized imaging data and were thus excluded, such as the study by Lingen et al, which included a cropped panoramic radiograph that exhibited a well-defined, corticated unilocular lesion in the posterior mandible with tooth displacement, but it was not mentioned which of the patients in their case report series corresponded to the image [8]. Like our exclusion criteria, Allon et al omitted a number of cases that were not truly intraosseous despite exhibiting bony changes in the mandible.

Our particular case has imaging features that are consistent with what has been reported in the past. And while CT findings are included in many of the existing case reports, our case is only the second known report to include CBCT findings, specifically. Findings in our case were similar to corresponding bone window MDCT, but it appeared that internal calcification was not as obvious in the CBCT. This could be due to lesion progression, as the CBCT was acquired 6 months before the MDCT. Also, the cortical boundary of the lesion appeared thinner in CBCT.

There were several limitations in our study. One is that we give data for prevalence of certain demographic parameters and imaging findings, despite excluding a few known reported cases of the condition that were omitted due to lack of individualized imaging findings. It is noteworthy that the total number of cases reported of intraosseous myofibroma of the jaws slightly exceeds 31 , to date. Another limitation is that in some cases, our observations of the images published in the articles did not fully correlate with the written description of the findings provided by the authors. However, we attempted to eliminate the possibility of erroneous reporting by entering "not reported" in doubtful cases. Many of the cases employed three-dimensional imaging, with a twodimensional image or two being included in the publication, rendering definitive extraction of information from the volume difficult. Another limitation is that descriptions of imaging findings can be subjective, such that there could conceivably be variability in reporting definition of the borders, internal contents or architecture, effects on adjacent anatomic entities including teeth, etc. Also, it is possible that certain types of findings that are more subtle or not often reported by non-radiologists, such as periosteal reaction, may not have caught the attention of/been included by some of the authors of these reports.

\section{Conclusions}

Intraosseous myofibromas of the jaws are rare, with a relatively small number of reported cases in the literature compared to some other more common jaw tumors. The purpose of this study was a) to report findings from our case to contribute to the existing body of evidence regarding imaging features of the central myofibroma, treatment modality and outcome, and b) to attempt to isolate and summarize the radiographic features of intraosseous myofibroma of the maxillofacial skeleton for the benefit of clinicians and radiologists subspecializing in the head and neck or maxillofacial regions. While intraosseous myofibroma of the jaws is quite rare, it may be considered in the differential diagnosis if the generalizable imaging and demographic features are present. This may be important as it, due to its rarity, has the potential of being overlooked as a possibility in the company of other more common cysts and tumors of the jaws with similar features. It also may masquerade as other pathosis that is aggressive or malignant, where diagnosis of myofibroma would be important to prevent over-aggressive treatment. Inclusion or consideration of the condition in a differential diagnosis may assist the clinician in the appropriate follow-up and/or management of the lesion.

\section{References}

1. Shibuya Y, Takeuchi J, Sakaguchi H, Yokoo S, Umeda M, et al. (2008) Myofibroma of the mandible. Kobe J Med Sci 54: E169-73.

2. Fletcher CDM, Unni KK, Mertes F (2002) WHO classification of tumors. Pathology and Genetics. Tumours of soft tissue and bone. IARC Press Lyon 59-61.

3. Jo VY, Fletcher CD (2014) WHO classification of soft tissue tumours: an update based on the 2013 (4th) edition. Pathology 46: $95-104$. 
4. Lopes RN, Alves FA, Roch AC, Suassuna TM, Kowalski LP, et al. (2015) Head and neck solitary infantile myofibroma: Cliniopathological and immunohistochemical features of a case series. Acta Histochem doi: 10.1016/j.acthis.2015.02.001.

5. Oudijk L, den Bakker MA, Hop WC, Cohen M, Charles AK, et al. (2012) Solitary, multifocal and generalized myofibromas: clinicopathological and immunohistochemical features of 114 cases. Histopathology 60: E1-11.

6. Hourani R, Taslakian B, Shabb NS, Nassar L, Hourani MH, et al. (2015) Fibroblastic and myofibroblastic tumors of the head and neck: comprehensive imagingbased review with pathologic correlation. Eur J Radiol 84: 250-60.

7. Allon I, Vered M, Buchner A, Dayan D (2007) Central (intraosseous) myofibroma of the mandible: clinical, radiologic, and histopathologic features of a rare lesion. Oral Surg Oral Med Oral Pathol Oral Radiol Endod 103: e45-53.

8. Lingen MW, Mostofi RS, Solt DB (1995) Myofibromas of the oral cavity. Oral Surg Oral Med Oral Pathol Oral Radiol 80: 297-302.

9. Lee YM, Son SM, Kim KW, Lee OJ (2014) Solitary myofibroma of the adult mandible: a case report and review of literature. Korean J Pathol 48: 307-10.

10. Rai B, Ludusan E, McGovern B, Sharif F (2014) Mandibular swelling in a 5-year-old child--mandibular myofibroma. BMJ Case Rep doi: 10.1136/bcr-2014203977.

11. Urs AB, Mohanty S, Arora S, Augustine J, Kumar P (2014) Pediatric solitary intraosseous infantile myofibroma of the mandible. J Dent Child (Chic) 81: $42-6$.

12. Damera NC, Vallabhaneni KC, Tripuraneni SC, Madala S, Diddi RR (2013) Non malignant maxillary lesions: our experience. Indian J Otolaryngol Head Neck Surg 65: 74-9.

13. Tabrizi R, Bahramnejhad E, Kazemi H, Asadzadeh M, Ranjbaran H (2013) Rapidly growing lesions involving the maxilla in infants: a two-case presentation and deferential diagnosis. J Craniofac Surg 24: e434-8.

14. Sundaravel S, Anuthama K, Prasad H, Sherlin HJ, Ilayaraja V (2013) Intraosseousmyofibroma of mandible: A rarity of jaws: With clinical, radiological, histopathological and immunohistochemical features. J Oral Maxillofac Pathol 17: 121-5.

15. Brierley DJ, Khurram SA, Speight PM (2013) Solitary myofibroma of the adult mandible: a case report. Oral Surg Oral Med Oral Pathol Oral Radiol 115: e40-3.

16. Haspel AC, Coviello VF, Stevens M, Robinson PG (2012) Myofibroma of the mandible in an infant: case report, review of the literature, and discussion. J Oral Maxillofac Surg 70: 1599-604.

17. Rokos J, Carlos R, Romañach MJ (2011) Clinical pathologic conference case 6: infantile myofibroma. Head Neck Pathol 5: 292-5.

18. Nirvikalpa N, Narayanan V (2011) Intraosseous infantile myofibroma of the mandible. Ann Maxillofac Surg 1: 87-90.

19. Ramadorai A, Rajsekaran A, Narayanan V (2010) A case report of solitary, intraosseous, adult-onset myofibroma of the mandible. J Maxillofac Oral Surg 9: 280-3.

20. Souza DP, Loureiro CC, Rejas RA, Sousa SO, Raitz R (2009) Intraosseous myofibroma simulating an odontogenic lesion. J Oral Sci 51: 307-11.

21. Odell EW, Aldred M, Carlos R, Curran A, Haikinheimo K, et al. (2004) Clinico-pathological conference 2002. Ann Acad Med Singapore 33: 53S-8S.

22. Sedghizadeh PP, Allen CM, Kalmar JR, Miloro M, Suster S (2004) Solitary central myofibroma presenting in the gnathic region. Ann Diag Pathol 8: 284-9.

23. Oliver RJ, Coulthard P, Carre C, Sloan P (2003) Solitary adult myofibroma of the mandible simulating an odontogenic cyst. Oral Oncol 39: 626-9.

24. Sugatami T, Inui M, Tagawa T, Seki Y, Mori A, et al. (1995) Myofibroma of the mandible: Clinicopathologic study and review of the literature. Oral Surg Oral Med Oral Pathol Oral Radiol Endod 80: 303-9.

25. Jones AC, Freedman PD, Kerpel SM (1994) Oral myofibromas: a report of 13 cases and review of the literature. J Oral Maxillofac Surg 52: 870-5.

26. Vigneswaran N, Boyd DL, Waldron CA (1992) Solitary infantile myofibromatosis of the mandible: Report of three cases. Oral Surg Oral Med Oral Pathol 73: $84-8$.

27. Matthews MM, Tabor MW, Thompson MS, Gross PD (1990) Infantile myofibromatosis of the mandible. J Oral Maxillofac Surg 48: 884-9.

28. Slootweg PJ, Muller H (1984) Localized infantile myofibromatosis: Report of a case originating in the mandible. J Maxillofac Surg 12: 86-9.

29. Satomi T, Kohno M, Enomoto A, Abukawa H, Fujikawa K, et al. (2014) Solitary myofibroma of the mandible: an immunohistochemical and ultrastructural study with a review of the literature. Med Mol Morphol 47: 176-83.

30. Tanaka Y, Yamada H, Saito T, Nakaoka K, Kumagai K, et al. (2014) Solitary myofibroma of the mandible in an adult with magnetic resonance imaging and positron emission tomography findings: a case report. World J Surg Oncol 12: 69.

31. Abramowicz S, Simon LE, Kozakewich HP, Perez-Atayde AR, Kaban LB, et al. (2012) Myofibromas of the jaws in children. J Oral Maxillofac Surg 70: 1880-4.

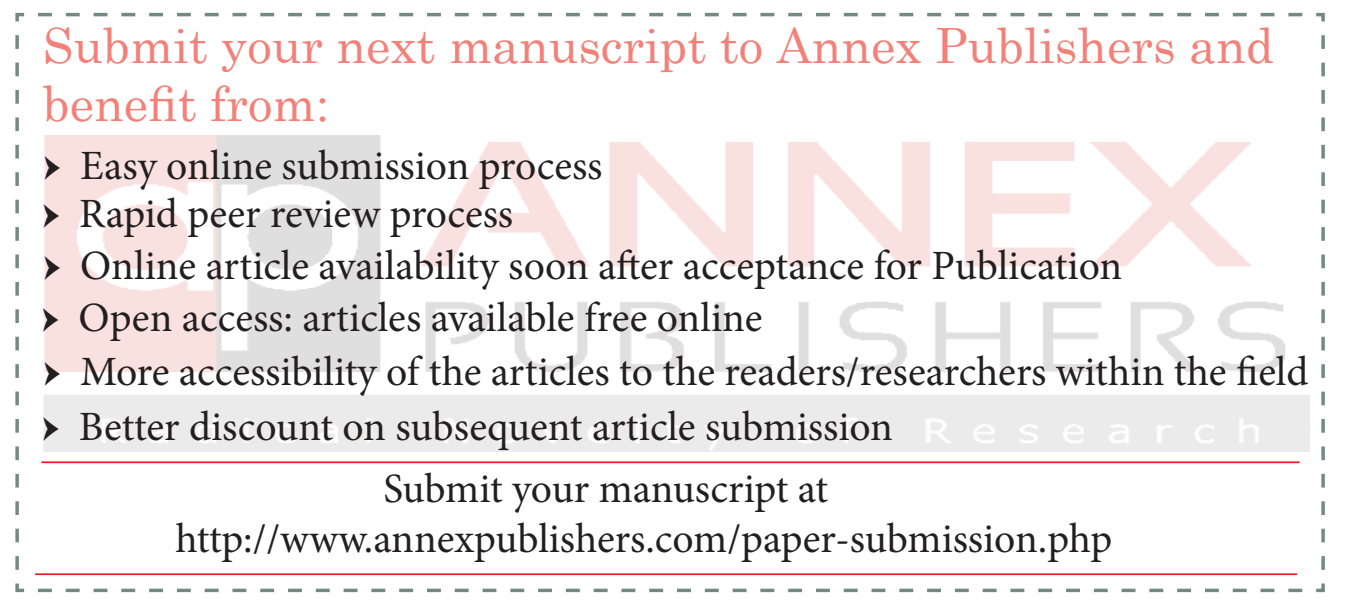

